\title{
Answers Blowing in the Wind: A Quarter Century of Genetic Studies of Pollination in Oaks
}

Mary V. Ashley

check for

updates

Citation: Ashley, M.V. Answers Blowing in the Wind: A Quarter Century of Genetic Studies of Pollination in Oaks. Forests 2021, 12, 575. https://doi.org/10.3390/ f12050575

Academic Editor: Stefan Arndt

Received: 19 April 2021

Accepted: 2 May 2021

Published: 5 May 2021

Publisher's Note: MDPI stays neutral with regard to jurisdictional claims in published maps and institutional affiliations.

Copyright: (C) 2021 by the author. Licensee MDPI, Basel, Switzerland. This article is an open access article distributed under the terms and conditions of the Creative Commons Attribution (CC BY) license (https:// creativecommons.org/licenses/by/ $4.0 /)$.
Department of Biological Sciences, University of Illinois at Chicago, Chicago, IL 60607, USA; ashley@uic.edu

\begin{abstract}
For the past 25 years, the twin tools of highly variable genetic markers (microsatellites) and paternity assignment have provided a powerful approach for investigating pollination patterns in trees, including many Quercus species. Early studies consistently demonstrated surprisingly abundant and extensive long-distance pollen movement in oaks. Indeed, numerous studies showed high levels of pollen immigration ( $50 \%$ or more), even for relatively isolated stands of oaks. Research also characterized fertilization patterns within stands and between hybridizing species in mixed stands. More recent studies have expanded our knowledge of genetic exchange effected by successful pollen movement, identified even more remarkable examples of the distances Quercus pollen can travel, and examined pollination patterns in relictual populations as well as those at the leading edges of range expansion. While the paradigm of long distance pollination continues to hold, a few recent studies that have also revealed the limits of pollen movement, identifying cases of reproductive isolation in extreme situations, where populations are at risk. This review will highlight what has been learned about Quercus pollination, what questions remain, and propose implications for forest management in the face of changing landscapes and climates.
\end{abstract}

Keywords: Quercus; pollination; microsatellites; parentage analysis; gene flow; wind pollination

Tracking pollination patterns is critical for understanding many fundamental aspects of Quercus biology, including reproductive patterns, impacts of habitat fragmentation, responses to climate change, and even masting dynamics. Prior to the availability of genetic markers to track pollen movement, characterizing pollination patterns in plants was difficult, especially for plants with wind-dispersed pollen such as members of the genus Quercus. Indirect approaches using pollen traps or dyes are logistically challenging, and only track the movement of pollen, not actual fertilizations. It has been about a quarter of a century since a class of genetic markers known as microsatellites were first applied to questions of pollen and seed dispersal in trees [1-4]. Also known as simple sequence repeats (SSRs) or short tandem repeats (STRs), these DNA sequences are repeated a dozen or more times. An important characteristic of microsatellites, and the source of their utility, is a high mutation rate for their number of repeat units. As a result, each microsatellite locus has many "alleles," variants that differ only by their number of repeats. These loci can be scored for length variants using a polymerase chain reaction (PCR) assay, and they provide a rich source of genetic markers for mating system studies such as the assignment of paternity [1,5].

Oaks were among the first systems where microsatellites combined with paternity assignment were used for describing pollination patterns $[3,4,6]$. Oaks are diploid, windpollinated and tend to occur in low diversity forests. The general approach for such studies would be to select an isolated stand or a portion of one where the density of trees was relatively low, so that a manageable number of reproductive adult trees could all be sampled. These adult trees would be genotyped at several microsatellite loci (typically 6-10). Acorns (or seedlings grown from acorns) would be sampled from a set of "maternal trees" and also genotyped. At every locus, the seed would have one maternal allele and one paternal allele. The genotypes of the other adults in the stand would be compared to assign 
paternity to one tree that could have contributed all of the paternal alleles. If no adult tree can be assigned, this indicated that the paternal tree was located beyond the study site and pollen immigration had occurred.

The concept of paternity assignment to track pollination patterns is straightforward, but in practice, there are several challenges that can complicate these studies. Advances in genetic marker availability and genotyping have helped ease technical issues that can occur in the lab, but genotyping is still not foolproof, and a small rate of error (including null alleles) must be accounted for. Paternity assignment by exclusion is unambiguous in principle but quite thorny in practice. Likelihood methods are usually employed but require estimates of parameters that may be uncertain, such as the proportion of candidate fathers sampled. Many of these issues and limitations are considered in more detail in Ashley [5]. For purposes of this review, I include studies conducted with an adequate set of markers and established analytical approaches, and I report the authors' conclusions regarding observed pollination patterns.

After developing the first microsatellite markers for oaks [7], Dow and Ashley investigated pollination and seed dispersal in a stand of bur oaks, Quercus macrocarpa, in Northern Illinois, USA $[3,4,8]$. Although the stand of 62 adult trees was relatively isolated, the researchers discovered that the majority of pollinations $(62 \%)$ were affected by trees outside the stand, at minimal distances of over $150 \mathrm{~m}$. For within-stand pollinations, the average pollination distance was $60 \mathrm{~m}$. Pollen donors were located in all parts of the stand and had a nearly random distribution around the maternal trees. These findings countered the prevailing view of pollination at the time, which envisioned a leptokurtic distribution around a single source with concentrations of pollen dropping rapidly with distance $[9,10]$. Indeed, distance between trees in a stand seemed to explain very little about the observed pollination patterns. Further investigations on Q. macrocarpa demonstrated that even extremely isolated stands of oaks receive large amounts of pollen from distant sources [11], and as a result, may be quite resilient to negative genetic consequences of habitat fragmentation [12].

Reports of substantial levels of long distance pollination in other species of Quercus in different habitats and continents began to appear. In a mixed stand of the European species Quercus robur and Q. petraea, gene flow from outside the stand exceeded $65 \%$ for both species [6]. In a later study involving a mixed stand of Q. petraea and Q. pyrenaica in central Spain [13], over a third of pollinations came from outside the stand for both species. Remarkably, within stand pollinations for Q. pyrenaica averaged $270 \mathrm{~m}$, comparable to the average pairwise distance between trees. In Japan, studies of $Q$. salicina showed a pollen immigration rate of $52 \%[14,15]$. A study of Quercus lobata in Coastal Central California found that $70 \%$ of effective pollen traveled more than $200 \mathrm{~m} \mathrm{[16].} \mathrm{Thus,} \mathrm{about} \mathrm{a} \mathrm{decade}$ ago, long distance pollination and high rates of pollen immigration emerged as the new paradigm for Quercus (and other wind pollinated trees), as a result of the application of paternity assignment and the availability of highly variable microsatellite markers [5].

These studies reported high levels of gene flow and pollination distances exceeding $100 \mathrm{~m}$, but they were constrained by sampling limitations in detecting just how far Quercus pollen might travel. The maximum distance that can be detected is the maximum distance between sampled trees in the study plot. Buschbom et al. [17] overcame that limitation by sampling a relict stand of $Q$. robur east of the Ural Mountains near Sibay, Russia. The stand is $30 \mathrm{~km}$ from another small relic stand and at least $80 \mathrm{~km}$ from the next closest oak occurrences. Remarkably, at least $35 \%$ of the acorns sampled there were the result of long-distance pollination, and most could not be assigned to trees in the other relict stand. This pushed the record of Quercus pollination distances to tens of kilometers. Substantial levels of pollen immigration have been reported at other isolated sites of Quercus (although none as isolated as the Sibay Q. robur stand). These include relict stands of Q. macrocarpa in agricultural landscapes of the midwestern USA [11] and low-density and highly fragmented stands of $Q$. ilex in Central Spain [18]. 
Studies began to investigate pollen movement in the context of deforestation and anthropogenic landscape changes. One interesting study was conducted on Quercus castanea, a species distributed from northern Mexico to Guatemala [19]. At the study site in Central Mexico, Q. castanea grew in fragmented forest patches and as isolated remnant trees. Gene flow via pollen was not reduced for the isolated trees, and the authors conclude that these scattered surviving trees facilitate gene flow and connectivity among forest patches. Another recent study of fragmented oak forests was conducted on Q. bambusifolia in Hong Kong [20]. While this study did not track contemporary pollen movement using paternity assignment, it did provide evidence for the role of pollen movement in the genetic recovery of Q. bambusifolia on Hong Kong Island since WWII, when forest cover was reduced to nearly zero. The authors identified only 11 trees (of 1138) with DBH (diameter at breast height) $>40 \mathrm{~cm}$ that were the likely survivors of deforestation. Genetic diversity increased in younger generations and genetic differentiation decreased, and the authors suggest that wind pollination over 70 years reduced the negative genetic consequences of severe forest loss and led to genetic recovery of the population.

While many oaks have suffered demographic declines and range reductions due to habitat loss, fragmentation, and climate change, some species are expanding their ranges polewards in response to warming climates. In a newly established population of $Q$. ilex growing more than $30 \mathrm{~km}$ ahead of other stands in southwestern France, Hampe et al. [21] report a remarkably high fraction of immigrant genotypes (27\%) in established offspring. These authors conclude that long-distance pollen flow can rapidly restore genetic diversity in leading-edge populations of oaks (and other wind-pollinated trees).

Studies have also used the microsatellite/paternity assignment approach to dig more deeply into Quercus male reproductive strategies. Lagache et al. [22] used a detailed paternity study and a spatially explicit individual-based mating model to investigate male fecundity in a mixed stand of $Q$. robur and $Q$. petraea. They report different male reproductive strategies for each species; $Q$. petraea trees dispersed their pollen over shorter distances and received less immigrant pollen than $Q$. robur. Quercus rober had a male reproductive strategy that favored pollen dispersal, having average pollen dispersal distances that were $40 \%$ greater than $Q$. petraea. There were also differences in interspecific sexual barriers, with $Q$. petraea having much stronger mating incompatibility. These results on differences in male reproductive strategies corresponded well to other evidence of these two species having different ecological strategies overall.

Rather than honing in on fine-scale details of pollination patterns at one site, Gerber et al. [23] chose to expand studies of pollination patterns across a much broader spatial scale. These authors studied gene flow (both pollen and seed dispersal) in eight mixed stands of white oak distributed across Europe, ranging from Spain to Sweden and Italy to Great Britain. The stands were mostly Q. petraea and Q. robur, but also included Q. pubescens and $Q$. faginea. The results of parentage analysis were used to simulate pollen (and seed) dispersal kernels using maximum likelihood. The results confirm that wind-borne pollen from outside the stand was high, $60 \%$ on average, but that it varied greatly among sites, ranging from $81 \%$ in Spain to $21 \%$ in the Denmark stand. Interestingly, pollen immigration rates were not correlated with stand size but estimated mean pollen dispersal distances were, ranging from $16 \mathrm{~m}$ in a small stand to almost $5400 \mathrm{~m}$ in a large stand. Long-distance dispersal events of almost $10 \mathrm{~km}$ were reported between scattered groups of trees.

Taken together, these recent studies further advance the paradigm of long distance pollen movement in oaks and extremely fat-tailed pollen dispersal kernels for their winddispersed pollen. As a consequence, even physically isolated oaks and oak stands are generally not reproductively isolated. Habitat loss and fragmentation will not likely signal a genetic doomsday for oak populations, although ecological and demographic losses loom large. However, some recent studies have revealed limitations and exceptions to the rule of long distance pollination, identifying populations that are experiencing restricted gene flow. A study of relictual populations of $Q$. robur at the extreme southwest edge of its range in western Spain reported that pollen exchange between stands was 
rare (2.6\%), and the median pollination distance was just $30.5 \mathrm{~m} \mathrm{[24].} \mathrm{The} \mathrm{restricted}$ pollen dispersal resulted in substantial levels of genetic differentiation among stands. These authors also documented a phenological effect, with late flowering stands receiving more immigrant pollen than early flowering stands. Another study is notable because of its focus on a neotropical oak, Q. segoviensis [25]. Some of the populations sampled at the southernmost extreme of the species range in Nicaragua showed reduced genetic variability and substantial genetic differentiation, indicating reproductive isolation over relatively small geographic distances. Another neotropical oak, Q. oleoides, at the southern periphery of its range also showed genetic differentiation among populations [26]. This study was noteworthy because the authors investigated the role of phenology, environment, and distance in explaining genetic structure. The authors report no evidence of phenological isolation or isolation-by-environment and conclude that limited pollen dispersal was the main contributor to population genetic structure. Further investigations of tropical oaks are needed to determine whether pollination distances are more restricted for these species than for temperate oaks, at least at the margins of species ranges. Interestingly, even species with extensive pollen movement may have isolated populations. Although long distance pollination has been est ablished for the California species Q. lobata [16], population and landscape analysis found that a topographic feature, likely a mountain range, appears to be a barrier to gene flow, isolating at least one population at the southern periphery of its range $[27,28]$.

Twenty-five years after researchers began using genetic markers to track pollination in oaks, we have gained a fairly detailed view of these patterns. In most, but not all, cases, we find evidence of extensive gene flow via pollen, and the only evidence to date of reproductive isolation occurs at the extreme peripheries of species ranges. This suggests that habitat fragmentation in oaks will generally not lead to genetic declines such as loss of genetic diversity. Both lagging- and leading-edge populations will continue to experience genetic exchange with core populations. Reestablishment or range expansion will be more constrained by arrival of acorns than by subsequent gene flow via pollen.

It is important to bear in mind that pollination distance is only one component of pollination biology, and that pollen abundance and pollen diversity are two different phenomena. Just because an oak tree will tend to receive pollen from near and far, and produce genetically diverse acorns, that does not preclude the possibility of pollen limitation for oaks. The studies cited here only document successful pollinations, but do not address the issue of whether pollen limitation (and reduced acorn production) occurs in either large stands or remote populations. Indeed, a number of studies have found a connection between masting in oaks and population-wide pollen availability [29,30]. For Q. lobata, high spring temperatures result in more synchronous flowering, which reduces pollen limitation and leads to high acorn production [30-32]. If phenological synchrony drives acorn production and masting behavior globally, an important but underappreciated ecological consequence of climate change could be changes in seed production patterns.

Another issue worth mentioning is also related to phenology. Because of long-distance pollination, most oaks will not be reproductively isolated by distance from other conspecifics; however, they may be isolated by flowering phenology. Different flowering times will isolate trees (or any plants) even if they are side by side. Microhabitat differences, local adaptation, climate change, and other factors may increase or decrease flowering synchrony and, thus, patterns of gene flow in oaks.

Finally, although the paradigm of long distance pollination in oaks has been firmly established over the last 25 years, it raises many intriguing questions for future studies in wind-pollination. How is it possible that the stigma of an oak flower gets fertilized by a pollen grain that has traveled hundreds of meters, rather than by the abundant pollen produced by neighboring trees? Could there be an element of female choice [33]? Does pollen have a maturation process that provides a fertility advantage for pollen that has been airborne for some time? Future oak research may reveal intriguing processes related 
to pollination, including phenological drivers, wind column dynamics, pollen properties, and mate choice. The next 25 years should bring exciting new insights.

Funding: This research received no external funding.

Conflicts of Interest: The authors declare no conflict of interest.

\section{References}

1. Ashley, M.V.; Dow, B.D. The use of microsatellite ahbnalysis in population biology: Background, methods and potential applications. EXS 1994, 69, 185-201. [PubMed]

2. Chase, M.R.; Moller, C.; Kesseli, R.; Bawa, K.S. Distant gene flow in tropical trees. Nature 1996, 383, 398-399. [CrossRef]

3. Dow, B.D.; Ashley, M.V. Microsatellite analysis of seed dispersal and parentage of saplings in bur oak. Quercus macrocarpa. Mol. Ecol. 1996, 5, 615-627. [CrossRef]

4. Dow, B.D.; Ashley, M.V. High levels of gene flow in bur oak revealed by paternity analysis using microsatellites. J. Hered. 1998, 89. [CrossRef]

5. Ashley, M.V. Plant parentage, pollination, and dispersal: How DNA microsatellites have altered the landscape. CRC. Crit. Rev. Plant Sci. 2010, 29, 148-161. [CrossRef]

6. Streiff, R.; Ducousso, A.; Lexer, C.; Steinkellner, H.; Gloessl, J.; Kremer, A. Pollen dispersal inferred from paternity analysis in a mixed oak stand of Quercus robur L. and Q. petraea (Matt.) Liebl. Mol. Ecol. 1999, 8, 831-841. [CrossRef]

7. Dow, B.D.; Ashley, M.V.; Howe, H.F. Characterization of highly variable (GA/CT) n microsatellites in the bur oak, Quercus macrocarpa. Theor. Appl. Genet. 1995, 91. [CrossRef]

8. Dow, B.D.B.D.; Ashley, M.V. Factors influencing male mating success in bur oak, Quercus macrocarpa. New For. 1998, 15, 161-180. [CrossRef]

9. Faegri, K.; van der Pijl, L. The Principles of Pollination Ecology; Pergamon Press: Oxford, UK, 1979; ISBN 9781483293035.

10. Okubo, A.; Levin, S.A. A theoretical framework for data analysis of wind dispersal of seeds and pollen. Ecology 1989, 70, 329-338. [CrossRef]

11. Craft, K.J.; Ashley, M.V. Pollen-mediated gene flow in isolated and continuous stands of bur oak, Quercus macrocarpa (Fagaceae). Am. J. Bot. 2010, 97, 1999-2006. [CrossRef] [PubMed]

12. Craft, K.J.; Ashley, M.V. Landscape genetic structure of bur oak (Quercus macrocarpa) savannas in Illinois. For. Ecol. Manag. 2007, 239, 13-20. [CrossRef]

13. Valbuena-Carabãa, M.; González-Martínez, S.C.; Sork, V.L.; Collada, C.; Soto, A.; Goicoechea, P.G.; Gil, L. Gene flow and hybridisation in a mixed oak forest (Quercus pyrenaica Willd. and Quercus petraea (Matts.) Liebl.) in central Spain. Heredity 2005, 95, 457-465. [CrossRef] [PubMed]

14. Nakanishi, A.; Tomaru, N.; Yoshimaru, H.; Manabe, T.; Yamamoto, S. Effects of seed- and pollen-mediated gene dispersal on genetic structure among Quercus salicina saplings. Heredity 2009, 102, 182-189. [CrossRef]

15. Nakanishi, A.; Tomaru, N.; Yoshimaru, H.; Kawahara, T.; Manabe, T.; Yamamoto, S. Patterns of pollen flow and genetic differentiation among pollen pools in Quercus salicina in a warm temperate old-growth evergreen broad-leaved forest. Silvae Genet. 2004, 53, 258-264. [CrossRef]

16. Abraham, S.T.; Zaya, D.N.; Koenig, W.D.; Ashley, M.V. Interspecific and intraspecific pollination patterns of valley oak, Quercus lobata, in a mixed stand in Coastal Central California. Int. J. Plant Sci. 2011, 172. [CrossRef]

17. Buschbom, J.; Yanbaev, Y.; Degen, B. Efficient long-distance gene glow into an isolated relict oak stand. J. Hered. 2011, 102, 464-472. [CrossRef]

18. Ortego, J.; Bonal, R.; Muñoz, A.; Aparicio, J.M. Extensive pollen immigration and no evidence of disrupted mating patterns or reproduction in a highly fragmented holm oak stand. J. Plant Ecol. 2014, 7, 384-395. [CrossRef]

19. Oyama, K.; Herrera-Arroyo, M.L.; Rocha-Ramírez, V.; Benítez-Malvido, J.; Ruiz-Sánchez, E.; González-Rodríguez, A. Gene flow interruption in a recently human-modified landscape: The value of isolated trees for the maintenance of genetic diversity in a Mexican endemic red oak. For. Ecol. Manag. 2017, 390, 27-35. [CrossRef]

20. Zeng, X.; Fischer, G.A. Wind pollination over 70 years reduces the negative genetic effects of severe forest fragmentation in the tropical oak Quercus bambusifolia. Heredity 2020, 124, 156-169. [CrossRef]

21. Hampe, A.; Pemonge, M.-H.; Petit, R.J. Efficient mitigation of founder effects during the establishment of a leading-edge oak population. Proc. R. Soc. B Biol. Sci. 2013, 280, 20131070. [CrossRef]

22. Lagache, L.; Klein, E.K.; Ducousso, A.; Petit, R.J. Distinct male reproductive strategies in two closely related oak species. Mol. Ecol. 2014, 23, 4331-4343. [CrossRef] [PubMed]

23. Gerber, S.; Chadœuf, J.; Gugerli, F.; Lascoux, M.; Buiteveld, J.; Cottrell, J.; Dounavi, A.; Fineschi, S.; Forrest, L.L.; Fogelqvist, J.; et al. High rates of gene flow by pollen and seed in oak populations across Europe. PLoS ONE 2014, 9, e85130. [CrossRef]

24. Moracho, E.; Moreno, G.; Jordano, P.; Hampe, A. Unusually limited pollen dispersal and connectivity of Pedunculate oak (Quercus robur) refugial populations at the species' southern range margin. Mol. Ecol. 2016, 25, 3319-3331. [CrossRef]

25. Ortego, J.; Bonal, R.; Muñoz, A.; Espelta, J.M. Living on the edge: The role of geography and environment in structuring genetic variation in the southernmost populations of a tropical oak. Plant Biol. 2015, 17, 676-683. [CrossRef] 
26. Deacon, N.J.; Cavender-Bares, J. Limited pollen dispersal contributes to population genetic structure but not local adaptation in Quercus oleoides Forests of Costa Rica. PLoS ONE 2015, 10, e0138783. [CrossRef] [PubMed]

27. Gharehaghaji, M.; Minor, E.S.; Ashley, M.V.; Abraham, S.T.; Koenig, W.D. Effects of landscape features on gene flow of valley oaks (Quercus lobata). Plant Ecol. 2017, 218, 487-499. [CrossRef]

28. Ashley, M.V.; Abraham, S.T.; Backs, J.R.; Koenig, W.D. Landscape genetics and population structure in Valley Oak (Quercus lobata Nee). Am. J. Bot. 2015, 102, 2124-2131. [CrossRef] [PubMed]

29. Koenig, W.D.; Ashley, M.V. Is pollen limited? The answer is blowin' in the wind. Trends Ecol. Evol. 2003, 18, S0169-S5347. [CrossRef]

30. Pesendorfer, M.B.; Koenig, W.D.; Pearse, I.S.; Knops, J.M.H.; Funk, K.A. Individual resource limitation combined with populationwide pollen availability drives masting in the valley oak (Quercus lobata). J. Ecol. 2016, 104, 637-645. [CrossRef]

31. Pearse, I.S.; Koenig, W.D.; Knops, J.M.H. Cues versus proximate drivers: Testing the mechanism behind masting behavior. Oikos 2014, 123, 179-184. [CrossRef]

32. Koenig, W.D.; Knops, J.M.H.; Carmen, W.J.; Pearse, I.S. What drives masting? The phenological synchrony hypothesis. Ecology 2015, 96, 184-192. [CrossRef] [PubMed]

33. Craft, K.J.; Brown, J.S.; Golubski, A.J.; Ashley, M.V. A model for polyandry in oaks via female choice: A rigged lottery. Evol. Ecol. Res. 2009, 11, 471-481. 